\title{
High and rising senior employment in the Nordic countries
}

\author{
Bjørn Einar Halvorsen
}

\section{Abstract}

The employment of older workers is high and rising in the Nordic countries, and most seniors have flexible access to employment or retirement from their early sixties on. However, there is still potential for further improvements, even in the Nordic countries. The article describes and analyses this development, and the main policies and reforms behind it in the Nordic countries over the last 20 years. The article is built on a report to the Swedish Governmental Delegation for the Promotion of Older Labour.

Keywords: Senior citizens, job longevity, work environment, employment conditions and retirement in the Nordics

\section{Introduction}

Most seniors in the Nordic countries continue in gainful employment beyond the age of 55 . This results in a high employment rate of older workers, compared with most other countries in Europe. In addition, the employment of older workers is rising remarkably over time. Much of this is due to the fact that new cohorts of seniors are consistently living longer, have better health and education, and many of them have had less physically demanding and health-risky jobs and working lives than previous generations of older workers.

The high and rising employment rate of older workers in the Nordic countries can also to some extent be explained by the policies that have been implemented in key areas. In some contexts, there is talk of a "Nordic model" for the economy, working life, social security and welfare. So also when it comes to older workers 'employment and retirement. Much has been done when it comes to active and inclusive labour market policies, early retirement and pension reforms. However, more could be done by promoting employers to retain and hire older workers, and by promoting their employability throughout the whole of working life.

This article describes and analyses what is happening in the Nordic countries in respect of:

- High and rising employment and good working conditions for most older workers, but also potential for further improvements 
- Economic policy aimed high employment and low unemployment

- Active and inclusive labour market policy and curbed early retirement

- Pensions- and retirement reforms

- Encouraging employers to retain and hire older workers

- Promoting employability throughout the whole working life

- Summary and concluding remarks

The article focuses on major national strategies, reforms and campaigns, as opposed to local measures at individual enterprises and workplaces. The text is mainly descriptive. The ambition is not to reveal causal relationships or effects of policies. This should be a task for closer research, I hope.

\section{High and rising senior employment, but still room for improvements}

The employment rates of older workers have increased markedly in the Nordic countries during the last 20 years (figure 1). The only exception is Iceland, where the employment rates of older workers are stable or slightly decreasing, but at a very high level. Except for Denmark, the employment of older workers also increased during the global financial crisis 2008-2010. We can hardly see any signs of the previous "lump-sum fallacy of labour" from the crisis about 20 years earlier, where a strategy was to try to reduce youth unemployment by extended early retirement of seniors.

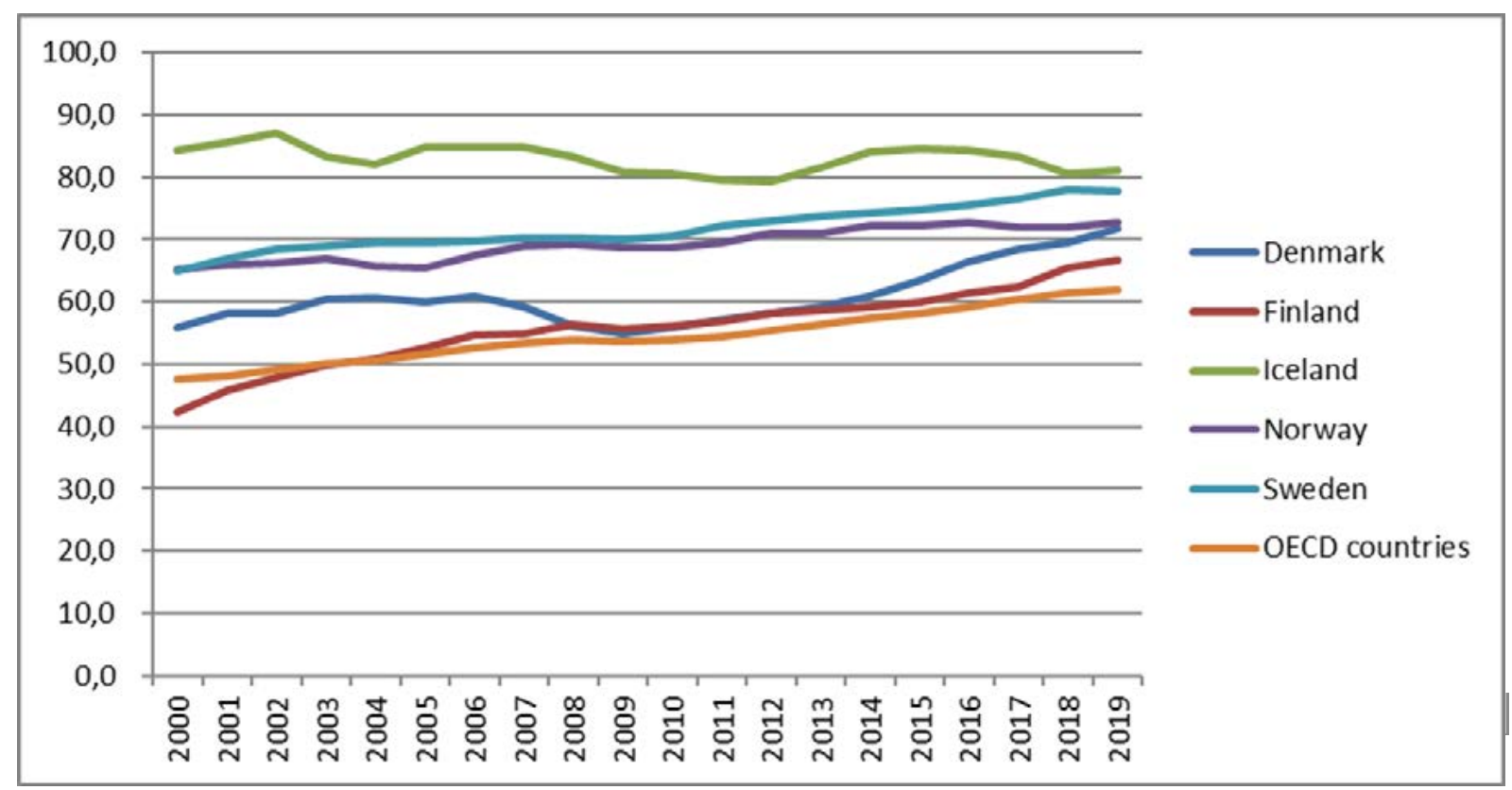

Figure 1. Employment rates 55-64 years old* in the Nordic countries 2000-2019

*Per cent of the population in each age group. Source: OECD Employment database

The employment rates of older workers are highest in Iceland, followed by Sweden and Norway. They are lowest in Finland and Denmark, but the senior employment rates have 
increased most in Denmark and Finland. The employment rates in the age group 55-64 in the years 2019/2000 respectively were: Denmark 72/56, Finland 67/42, Iceland 81/84, Norway 73/65, Sweden 78/65 and OECD total 62/48.

The employment rates are relatively high among both men and women in the Nordic countries, with relatively small differences between the sexes (figure 2). In Finland there is even slightly higher employment among women than among men in this age group (55-64). The employment rates (\%) among men / women respectively in this age group in 2019 were: Denmark 76/68, Finland 65/69, Iceland 87/75, Norway 77/69, Sweden 80/76.

In other European countries with relative high employment rates, they have greater differences between men and women (Germany, Netherlands, Switzerland, Czech Republic). In other European countries, the employment rates are considerably lower among both women and men (Belgium, France, Italy, Greece and Poland). The average employment rates for all OECD countries in 2019 was 71\% among men and 54\% among women aged 55-64 years old.

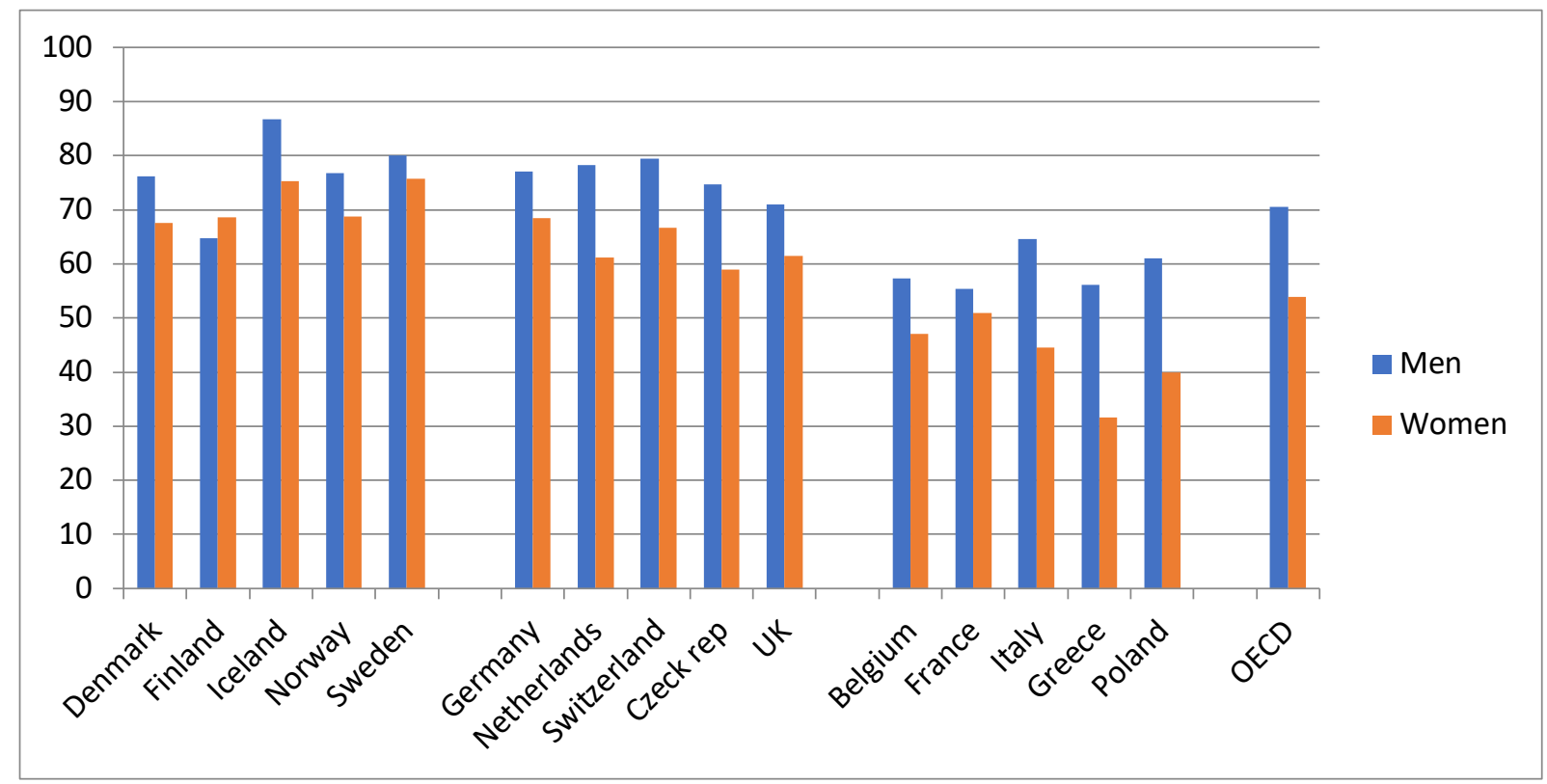

Figure 2. Employment rates 55-64 years. Men and women. Selected OECD countries 2019

Table 1 shows employment (\%) in five-year age groups between the ages of 55 and 75 years in the Nordic countries in the years 2000 and 2019. There has been strong employment growth in all the senior age groups in all Nordic countries, except for Iceland, where they are slightly decreasing. The increase has been especially high among people in their sixties. 
Table 1. Senior employment rates in the Nordic countries. Percentage of five-year age groups

\begin{tabular}{ccccccccccc} 
& \multicolumn{2}{c}{ Denmark } & \multicolumn{2}{c}{ Finland } & \multicolumn{2}{c}{ Iceland } & \multicolumn{2}{c}{ Norway } & \multicolumn{2}{c}{ Sweden } \\
Age group & 200 & 201 & 200 & 201 & 200 & 2019 & 200 & 2019 & 200 & 2019 \\
& 0 & 9 & 0 & 9 & 0 & & 0 & & 0 & \\
\hline 55-59 years & 73 & 83 & 59 & 79 & 88 & 84 & 77 & 80 & 78 & 85 \\
60-64 years & 34 & 60 & 23 & 54 & 80 & 78 & 54 & 65 & 48 & 70 \\
65-69 years & 8 & 22 & 5 & 15 & 49 & 50 & 18 & 30 & 15 & 24 \\
70-74 years & 4 & 8 & 2 & 7 & 17 & 15 & 4 & 7 & 6 & 11 \\
\hline Source: OECD Employment database 2019. Labour force surveys (LFS)
\end{tabular}

There are stepwise decreases in employment rates around the ages of 60, 65 and 70 years in all the countries. This is at the ages where it was previously normal (or compulsory) to retire. This means that there is potential for higher employment among people also older than 60 years in the Nordic countries in the future.

Table 2 below shows a number of supplementary indicators for the situation in the labour market and working life environment, for seniors in the Nordic countries and for the OECD.

Table 2 Working life indicators for older workers in the Nordic countries and OECD 2018

\begin{tabular}{lcccccc} 
& Denmark & Finland & Iceland & Norway & Sweden & OECD \\
\hline Employment rate 55-74 years (\%) & 52 & 49 & 69 & 56 & 58 & 51 \\
Employment gap W/M 55-64 & 9 & -2 & 11 & 8 & 4 & 14 \\
years (\%) & & & & & & \\
Part-time job 55-64 years (\%) & 15 & 16 & 19 & 24 & 21 & 20 \\
Temporary job 55-64 years (\%) & 4 & 9 & 3 & 2 & 7 & 7 \\
Self-employed (\%) & 10 & 17 & 19 & 8 & 14 & 21 \\
Retention rate 60-64 years (\%) 1) & 50 & 51 & 80 & 70 & 64 & 47 \\
Hiring rate 55-64 years (\%) 2) & 8 & 10 & 5 & 4 & 9 & 9 \\
Unemployment 55-64 years (\%) & 4 & 7 & 2 & 2 & 5 & 5 \\
Of which unemployed > 1 year (\%) & 42 & 40 & 27 & 31 & 29 & 46 \\
Higher education 55-64 years (\%) & 29 & 40 & 31 & 34 & 33 & 27 \\
Participated in learning 55-64 & 44 & 40 &.. & 54 & 57 & 42 \\
years (\%) & & & & \\
Source: OECD Older Workers Scoreboard 2018 & & & & \\
Notes: 1) The proportion of workers aged 60-64 years who were in the same job five years earlier. \\
2) Proportion of workers aged 55-64 years who have been employed for less than one year in the same job.
\end{tabular}

Table 2 indicates that working life quality for older workers is generally good on average, as measured by these indicators. There are also certain nuances and differences between the Nordic countries. The table shows that: 
- The employment rate among people aged 50-74 years is higher than 50\%, and highest in Iceland, followed by Sweden and Norway.

- The employment gap between older women and men is fairly low: 8-10\% difference in Denmark, Norway and Iceland, and 4\% difference in Sweden. Finland has slightly (2\%) higher employment among older women than among older men.

- The proportion of seniors (55-64) in a part-time job is quite low, and varies between 15\% (Denmark) and 24\% (Norway).

- The proportion of older workers (55-64) in a temporary job is lower than $10 \%$, and is especially low in Norway, Iceland and Denmark (2-4\%)

- The proportion of self-employed older workers (55-64) varies between 8-10\% in Norway and Denmark and as high as 17-19\% in Finland and Iceland respectively.

- More than 50\% of older workers (60-64 years) have been in the same job for more than five years. This retention rate is highest in Iceland (80\%), followed by Norway (70\%) and Sweden (64\%).

- Less than $10 \%$ of older workers (55-64) have recently been hired for a new job. They have been employed in their current position for less than one year. Iceland and Norway have the lowest hiring rates, and Finland and Sweden have the highest ones.

- Unemployment among older workers (55-64) is low. It is lowest in Iceland and Norway (around 2\%) and highest in Finland (7\%).

- By contrast, the proportion of long-term unemployed (> 1 year) among the unemployed older workers (55-64) is high: About 25\% in Iceland, 30\% in Norway and Sweden, and 40\% in Denmark and Finland.

- The proportion of older workers (55-64) with higher education is around 30\% in all the Nordic countries except in Finland, where 40\% have higher education.

- Between 40\% (Finland and Denmark) and 50-60\% (Norway and Sweden) of older workers (55-64) have participated in learning activities during the last year.

The OECD report Working Better with Age (2019) gives a broad status and analysis about the situation and development for older workers in the OECD countries. The report confirms the relatively good situation and development in the Nordic countries. The conclusion is still that all countries: the Nordics included, should take further actions to boost the job opportunities at an older age. OECD recommends governments to take further actions in three broad areas:

- Rewarding work at an older age

- Encouraging employers to retain and hire older workers

- Promoting employability of workers throughout their whole working lives

Most political focus and reforms have been implemented within the first one of these broad areas, mainly by better work incentives, pension reforms and early retirement reforms. However, more can be done especially within the two other areas, says the OECD. Within the second area by addressing negative ageist attitudes and age discrimination in recruitment, promotion and retention, and by encouraging good practice by employers and leaders in 
managing an age-diverse workforce. Within the third area by improving lifelong learning and skills recognition, by improving working conditions and job quality at all ages, and by providing effective employment assistance for older workers facing job loss or wish to find another job. These are important challenges and areas for improvement in the Nordic countries as well.

\section{Economic policy aimed high employment and low unemployment}

An important underlying factor behind the high and rising employment of older workers in the Nordic countries is the proactive, stabilising and inclusive economic policy that has been pursued. This has led to stable economic growth, high and stable employment, and low unemployment rates in countries.

Like most other countries, the Nordics suffered a sudden decline in the economy during the global financial crisis of 2008-2010, but the economic development stabilised rather quickly thereafter. The financial crisis had greater impact on the economy of most other Western OECD countries than in the Nordic countries, except for Iceland. The reasons are related to the economic policy and the labour market systems in the Nordic countries. Important advantages in the Nordic countries include:

- Stable, predictable institutional framework conditions

- Stabilising fiscal policy and monetary policy

- Tripartite collaboration on pay, employment and social welfare

- Active labour market policy

- A relatively high overall level of education in the population

- Social security for all through universal and relatively good social insurance schemes

This both presupposes and entails joint responsibility and mutual trust among people and between the people and the governmental institutions. (Andersen, Dølvik \& Ibsen, 2014)

\section{Active and inclusive labour market policy and curbed early retirement}

All the Nordic countries pursue an active and inclusive labour market policy and working environment policy, on the basis of good regulations and institutions. Most policies and instruments are universally designed, with mainly equal individual rights and duties for everyone, regardless of their age, gender and other characteristics. Older workers are covered by the universal instruments in the same way as everyone else. There are also a number of measures and programmes that target older employees and jobseekers in particular. The situation for seniors on the labour market in the Nordic countries must therefore be considered in light of both universal schemes as well as more targeted programmes. 
Denmark: Denmark has attracted international interest for its "flexicurity model" in the employment market ("easy to hire and easy to fire"). This entails relatively weak, by Nordic standards, employment protection rights, combined with fairly good social insurances and a very active labour market policy. Denmark's labour market policy in recent years represents something of a U-turn from its previous policy of encouraging early departure from working life. The voluntary early retirement pension scheme ("efterløn") and other early retirement pensions have gradually been reformed and curbed, in favour of good incentives to continue working for longer. A number of political package deals have been assessed, processed and implemented. The Employment Reform (2015) was specifically aimed at people over the age of 50 at risk of long-term unemployment and possibly falling out of the labour market.

Finland: Finland's working life policy in the 2000s has mainly focused on addressing a combined stagnation and transition in the economy, combined with extensive early departure from working life. Several programmes and schemes have been implemented to promote a return to work and retraining for a new job and education in connection with staff cuts. In addition, there have been various working environment programmes to promote human relations management with a focus on older workers and a life-cycle approach, as well as for a good health and quality situation at the workplaces. An "unemployment tunnel" of extended and longer unemployment benefits for older people (55-65) into retirement has gradually been dismantled.

Iceland: The labour market in Iceland is quite flexible. There have been enormous changes in the wake of the financial collapse in 2008-2010. Iceland has the highest employment rate and lowest unemployment rate in the whole OECD area. Iceland has mainly not implemented new types of extensive active labour market measures. However, the government has recently drawn up a policy to help more older workers stay even longer in the workforce. Older workers can gradually switch to less physically demanding jobs and perhaps slightly less responsibility and a slower pace: in a mutual understanding of their own and the company's preferences. There is however, a significant early departure from working life by a disability pension.

Norway: Tripartite collaboration between the government and the social partners by income negotiations and in the labour market- and social policies is essential in Norway. This has led to good overall achievements when it comes to employment and working conditions, and not the least for older workers. The Labour and Welfare Administration (NAV) offers a number of types of labour market measures, and NAV also offers all types of public social insurance benefits for all Norwegians. Older workers are not a certain priority group for active labour market schemes, but they are overrepresented among the long-term unemployed, which is a priority group. There is widespread early departure from working life through disability pension in Norway, however. Much of this has its background in restructuring and downsizing of enterprises and workplaces (Halvorsen, 2019). 
A government-appointed Employment Committee has last year delivered a preliminary report on improved policies and measures that can contribute to more people working and fewer people ending up on disability benefits (NOU 2019:17)

Sweden: There are few ALM programmes that are specifically aimed at seniors in Sweden. However, how they are implemented, dimensioned and practised can often be adjusted to target specific groups, such as older workers and long-term unemployed. Sweden has had good results by using positive economic incentives to promote employment of older jobseekers and other more vulnerable groups in the labour market. Sweden has also a good tradition and good achievements by working systematically with managing organisational restructuring and downsizing in businesses and working life in the best possible way for affected employers and employees. There was previously a high prevalence of sickness absence and disability retirement in Sweden. Introduction of guideline-limits on the duration of sickness benefit and an active rehabilitation chain are the key reform elements to curb this trend. The result is lower sickness absence and fewer people on disability pension, but on the other hand also higher unemployment and more people receiving social cash benefits.

\section{Pensions and retirement reforms}

There have been, and continue to be, extensive pension reforms implemented in all the Nordic countries. The main objective is to make the pension systems more sustainable in the long term with good intergenerational balance of benefits and costs. Incentives and mechanisms to stimulate to longer working lives and greater flexibility in the transition between work and retirement are central.

Denmark: The retirement reforms in Denmark have mainly focused on gradually raising the official retirement age and early retirement ages, and shortening the maximum period of early retirement pension:

- The general retirement age is going to be raised gradually from 65 years to 67 years.

- The voluntary early retirement pension age is being raised from 60 to 62 years.

- Longevity indexing of these age limits for receiving a pension in the longer term.

- Reductions of voluntary early retirement pension against old-age pension.

- More favourable reduction of old-age pension against earned income.

- "Seniors early retirement" for people who have less than five years until they reach retirement age and who are no longer able to continue working.

Work has also been initiated to simplify and improve the incentives to carry on working in respect of means-testing and reduction of different types of pension benefits against each other and against earned income. A new "years-of service" early retirement pension will be implemented from 2022, targeted towards persons 61 years and older with long and physically hard-working lives behind them. 
Finland: Finland has implemented several pension reforms and has others in the pipeline. The main objective is more sustainable pensions in the long run by encouraging higher employment and a longer and better working life for older workers. The 2017 pension reform shall contribute to this, while ensuring adequate income for future retirees. A longer working life will yield higher annual pensions. The earliest possible retirement age is gradually being raised from 63 to 65 years up to 2027. From 2030, the future retirement age will be indexed in accordance with development in the expected remaining life expectancy of the relevant age cohorts. The reform also introduces incentives to continue working beyond the retirement age. Longevity indexation of accumulated pension rights earned from work has been introduced.

A flexible partial pension can be drawn as $25 \%$ or $50 \%$ of the accumulated pension from the age of 61, and from 64 years for people born in or after 1964. This lower age limit will also be indexed on the basis of expected remaining life expectancy starting from 2030. A new "yearsof-service pension" was also introduced in connection with the 2017 pension reform. The pension is targeted towards older persons $(61+)$ with reduced work capacity after long and physically demanding working careers.

Iceland: The general retirement age is 67 years, with a requirement of 40 years' residence to receive a full basic pension and 40 years' accumulation of pension savings to qualify for a full supplementary pension. The law on mandatory supplementary pension (occupational pension) entered into force in 1998, so no-one has yet earned a full supplementary pension. The earned supplementary pension can be drawn from the age of 60 years or deferred up until the age of 72 years, against deductions from - or additions to the annual pension respectively. From 2018, it is possible to draw half the supplementary pension against a corresponding reduction in working hours. The government aims to rise the general retirement age gradually from 67 to 70 years.

Norway: The 2011 pension reform: The overall pension system in Norway has gradually been reformed since 2011, inspired by the Swedish pension reform some ten years earlier. The objective is a more sustainable system with better intergenerational balance. The main elements of the pension reform in the Norwegian National Insurance Scheme are:

- Pensions earnings on all earned income throughout the entire working life. 18\% of the annual work income up to a certain threshold is saved into an individual pension account, which is to be distributed over all the years of retirement.

- A guaranteed minimum pension for people with low pension earnings. Minimum level approx. NOK 200,000 (EUR 20.000) with 40 years' residence in Norway, and a lower level with shorter length of residence. Reduced by $80 \%$ against the earned pension.

- Flexible retirement age and pension withdrawals between the ages of 62 and 75 , based on cost neutrality. Early pension withdrawal results in a lower annual pension, and vice versa. 
- Longevity indexing of the accumulated pension account. Increasing longevity leads to lower pension per year, or you have to work longer for a certain pension level per year

- Accumulated pension assets are indexed in line with the overall wage increases, while the paid pension is adjusted $0.75 \%$ lower than the annual wage increases.

Pension payments are not means-tested (reduced) against income from work. Individuals are free to draw pension and continue working. Supplementary contractual pensions and occupational pensions are gradually being adapted to the reformed Norwegian National Insurance Scheme.

Sweden: The Swedish pension reform that took place some 20 years ago has acted as a template for pension reforms in many other countries. The core of the reform was to combine good characteristics of a defined-benefit system and a defined-contribution system. The main elements of the reform are:

- A transition from a "defined-benefit" system to a "listed defined-contribution" system. An annual pension premium of $16 \%$ of the annual income is accumulated over the individual's entire working life, in an individual pension account that is to be distributed over the expected number of years of retirement - The General Pension (AP).

- The individual's pension earnings are proportional with their annual income, with premiums paid over their entire working life, as compared with the previous system based on the income in the 15 best of 30 years.

- Flexible access to draw a full or partial pension from the age of 61 years. The longer the individual waits to start drawing their pension, the higher the annual pension they receive.

- A fund-based, individual, premium pension was introduced. 2,5\% of the annual income is paid into an investment fund with individual investment choices.

- Guaranteed minimum pension from the age of 65 years for people with low or no earnings in the General Pension (AP) scheme.

The future rules regarding retirement age and age limits will be linked to the development in average life expectancy through a "target age" ("riktålder') system. This means that all the age limits in the pension system and in the rest of the social security system will be linked to life expectancy. The lowest age at which people can start drawing the general pension (AP) is going to be raised gradually from 61 years to 64 years. The age from which the guaranteed minimum pension can be drawn is going to be raised gradually from 65 to 66 years and eventually up to the future new "target age".

\section{Encouraging employers to retain and hire older workers}

«Employers play a key role in promoting longer working lives by offering older workers good employment opportunities. However, they may be hesitant to retain and hire older workers because of actual or perceived gap between the costs of 
employing older workers and their productivity. They may also have stereotypical views about the lack of adaptability and flexibility of older workers. Public policy in OECD countries have addressed these challenges in three main ways: action to ban age-discrimination; measures to facilitate retention and hiring (....); and encouraging the use of age management practices to enhance the employability and productivity of older workers. » (OECD, 2019, chapter 4)

Most initiatives and reforms to increase the labour market participation of older workers have so far been implemented on the supply side of the labour market. In particular by strengthened work incentives in pension reforms and active labour market measures. There have been fewer and weaker initiatives on the demand side of the labour market. Namely by encouraging employers to retain and hire older workers. Employers are usually more willing to retain than to hire older workers. The retention rates of older workers are pretty high and the hiring rates pretty low in the Nordic countries (OECD, 2019, and table 2 in this article).

Age discrimination in the labour market is forbidden by law in the Nordic countries, but age stereotypical attitudes and behaviour exist (SOU 2020:69). This is most common when it comes to recruitment and hiring processes. Employers and line managers often appreciate their older employees, because of their work experience, loyalty, stability and responsibility. But they are more hesitant to hire older workers: the main reason may be actual or perceived obsolete competence and reduced productivity.

In three of the Nordic countries: Denmark, Norway and Sweden, the governments have set up national and tripartite anchored institutions to provide knowledge-based information, advice and awareness-raising about such kinds of issues and questions:

Denmark: The Seniors Think Tank for a longer, good working life. ${ }^{1}$ The Think Tank was set up in 2018, with the objective to help ensure that seniors can have a better and longer working life, and to get more people to defer starting to draw their pension.

Norway: Centre for Senior Policy (CSP). ${ }^{2}$ CSP is a national resource centre that aims to stimulate the integration and promotion of a senior's perspective in companies' human relations (HR) policy and management.

Sweden: Delegation for Senior Labour. ${ }^{3}$ The delegation was set up by the Government in 2018 to promote older workers, counteract age discrimination, and identify opportunities to make better use of older workers' experience and competencies. The objective is to work for a more inclusive and age-neutral working life.

\footnotetext{
${ }^{1}$ www.seniortaenketanken.dk

${ }^{2}$ www.seniorpolitikk.no

${ }^{3}$ www.seniorarbetskraft.se
} 
The Danish think tank and the Swedish delegation completed their work in 2019 and 2020 respectively, while the Norwegian CSP is permanent. However, the two former institutions in their final reports have recommended some kind of permanent solutions for such purposes in Denmark and Sweden, like there is in Norway.

The Danish Think Tank has published a range of analyses, and good practice examples of senior policies and how to improve the senior policy at enterprise level. Their final report contains 20 concrete recommendations to the government and the social partners about how more seniors can experience more good years in working life. The first and main recommendation is that the Government and the social partners should establish a permanent partnership for further increasing of senior employment. Developing a system for experience- and real-competence judgement and qualifications is another recommendation. Local jobcentres (PES) should be given improved opportunities and options for practical competence-judgement and further qualifications (Seniortænketanken 2020)

The Norwegian Centre for Senior Policy (CSP) is tasked with promoting, gathering and informing about scientific research as well as first-hand cases and good practical examples of senior policy in the working life. CSP initiates research and pilot projects, they arrange seminars and conferences and issues publications on senior policy questions. A «Senior Policy Barometer» containing systematized attitudes among employees and employers/leaders is each year being issued, presented and discussed by the social partners, policy makers, enterprises and researchers. (Norsk Seniorpolitisk barometer, 2019 and 2020). A core priority for the CSP is also to stimulate good human relations policy and -practice with a good life-long perspective. Such kinds of studies and projects are being carried out in a practical setting in specific sectors and branches of the labour market, such as industry-, trade-, education -and care sectors.

The Swedish Delegation for Senior Labour has published a number of papers and reports on different kind of issues pertaining to senior workers. The delegation also undertook studyand co-operation visits to labour market organisations and enterprises, in order to learn about- and provide information on current senior policy issues and programmes. The «delegation ambassadors» have published articles and made presentations about such issues in the mass media, and have participated actively in public debate. The Delegation `s main, final considerations are that (1) the competencies and experiences of senior workers should be better acknowledged, appreciated and used, (2) a longer working life presupposes lifelong learning, and (3) formal age limits and regulations are affecting the length of the working life. Their main recommendation is to continue and develop the knowledge and information about seniors and work, and to influence attitudes and behaviour on a permanent basis (SOU 2020:69) 


\section{Promoting employability throughout the whole working life}

The OECD-report Working Better with Age (2019) pointed out skills development and lifelong learning as an important area for further development and improvements of the future employment of seniors and older workers:

«The best practice for strengthening employability and job opportunities at an older is to provide equal opportunities for workers to continuously upgrade their skills, recognise skills acquired throughout their working lives and improve working conditions at all ages. This prevention strategy should be the motto of a work culture promoting longer and better working lives. » (OECD, 2019, chapter 5)

Results from the OECD Survey of Adult Skills (PIAAC) suggest that older workers across the OECD are not, on average, well equipped to deal with changes in skill requirements brought about by technological progress and globalisation. The ability to solve problems in technology-rich environments are, still on average, markedly lower than among their younger colleagues. This is to a certain extent the situation in the Nordic countries as well (OECD, 2016). Older workers with less recent vintages of skills are particularly exposed to the risk of skills obsolescence. In addition, older workers participate far less than younger workers in job-related training, (OECD, 2019). Older jobseekers have also often severe problems by getting a new job after enterprise restructuring and downsizing. A lot of them leave the labour market into (too) early retirement (Halvorsen, 2019).

Such challenges are broadly acknowledged in the Nordic countries, and highlighted in several governmental policy documents and initiatives. Some concrete policy initiatives have also been implemented, but more could be done, especially in practice and at the enterprise level.

Here are some examples of recent national initiatives and programmes in the Nordic countries: (source Halvorsen, 2020)

The Danish public employment centres (PES/Jobcentre) provide a wide range of active labour market service measures in their toolbox. Among them also several programmes for joboriented adult training, learning and education, both for jobseekers as well as for employed workers. The programmes contain both short-time job-training courses and vocational educations, as well as supplementary educations up to bachelor-level. The duration varies from 3-4 months up to 3-4 years. Most programmes are free of charge, and the participants usually receive a wage- or financial support during their participation in training or education programmes. For academic education you usually do not receive a wage remuneration, and usually you have to pay a subsidised participant's fee.

In Finland there are several programmes and initiatives to promote reemployment after redundancy, such as the «New security, new skil/s» programme. This is a programme that provides early intervention in the form of personal advice, guidance, support and follow-up services for workers who are laid off or made redundant; organisational restructuring, as well 
as for employers and line managers, to help them carry out such restructuring processes in a best possible way. The programme is more tailored towards white-collar workers than towards blue-collar workers. Finland has also several national and local initiatives and programmes focusing on age-based and life-cycle-oriented work management and quality. A National Working Life Development Strategy aims at increased employment, productivity and quality in the working life, as well as employee`s wellbeing at work. A programme named "Competence Based Qualifications», recognises competencies acquired during the worklife, and offers the possibility to complete a vocational upper secondary qualification, further vocational qualifications and specialist vocational qualifications.

In Iceland a new law on adult education was adopted in 2010. The goal is to raise the level of education in the adult population, and especially among people with little formal education. The principle is that everyone should have the opportunity to take education, and develop their competences during their whole lives.

In Norway there is an ongoing tripartite National Competence-policy Strategy (Nasjonal Kompetansepolitisk Strategi for 2017-2021). Lifelong learning and competence acquirement at work is one of the (3) main goals for the strategy. Among the more concrete initiatives are: Strengthen and develop the digital competence in the entire workforce. Strengthen and develop vocational education and career ways. Improved regional career-guidance services. More active use of training and competence-building measures in the labour market- and integration policies. Strengthen the PES`s (NAV`s) learning- and training services for jobseekers who need better qualifications to get a job. The Government in 2020 launched a White Paper for the Parliament on Competence reform on lifelong learning (Melding til Stortinget 14 for 2019-2020). The main goals are that nobody should be outdated because of lack of competence, and to tighten gaps between the workers' competencies and what working life needs. Three main programme-areas for action are pointed out: (1) Financial support to flexible, higher education for adults, (2) Tripartite sector-programmes for competence-development, and (3) Pilot projects for financial incentives for life-long learning.

Sweden has a good tradition of working systematically to handle and manage necessary restructuring and downsizing of enterprises and workplaces, in the best possible ways for affected employers and employees. The Security Council (Trygghetsrådet TRR) works as a longterm consult and partner and provides professional counseling, guidance and support to managers, employees and local trade unions during major restructuring or downsizing processes. The Employment Transition Fund (Trygghetsfonden TSL) is another, similar agency, more aimed at blue-collar workers than TRR. The achievements of the TRR and TSL services are pretty good: Between 7-9 out of 10 of the affected workers get a new job or a career shift through the co-operation with TRR or TSL. To facilitate the continuous restructuring in the labour market, the government have introduced opportunities for employees to develop and their competencies, or to learn new skills during their whole working lives. A paid period for personal professional development for up to one year will be provided. 
In all the Nordic countries, several packages of extended financial support to job-oriented adult training, learning and further education have been launched during the last year, as elements of the Governments` «Corona-pandemic strategies».

\section{Summary and concluding remarks}

The employment of older workers is high and rising in the Nordic countries during the last 20 years. The employment rates among people 55 years old and older is highest in Iceland, followed by Sweden and Norway, but have increased most in Denmark and Finland during the last 3-5 years. The senior employment rates are relatively high both for men and women, compared to most other European countries. There are stepwise decreases in employment rates around the ages of 60,65 and 70 years in all the countries. This is at the ages when it previously was normal (or compulsory) to retire, due to formal retirement ages. This means that there is potential for higher employment among people older than 60 years in the Nordic countries in the future.

The OECD has recommended governments to take actions for further improvements of the seniors `employment in three broad areas (OECD, 2019):

- Rewarding work at an older age

- Encouraging employers to retain and hire older workers

- Promoting employability of workers throughout their whole working lives

Most political focus and reforms have been implemented within the first of these broad areas, mainly by better work incentives, pension reforms and early retirement reforms. However, more can be done within the two other areas, say the OECD. This is relevant for the Nordic countries as well.

An important underlying factor behind the high and rising employment of older workers in the Nordic countries is the stabilising and inclusive economic policy that has been pursued. This has led to stable economic growth, high and stable overall employment and low unemployment rates in countries.

All the Nordic countries pursue an active and inclusive labour market policy and working environment policy, on the basis of good regulations and institutions. Tripartite co-operation between the governments and the social partners is essential. Most programmes and measures are universally designed, with mainly equal individual rights and duties for everyone, regardless of their age and gender and so on. Older workers are covered by the universal measures in the same way as everyone else. There are also some measures and programmes that are more targeted and tailored towards older employees and jobseekers.

A big challenge is the severe ongoing and future structural transitions in the labour markets. This has accelerated tremendously during the ongoing global corona pandemic crisis. We 
know that older workers have great problems in getting a new job after enterprise downsizing, and many of them leave the labour market into (too) early retirement. In Sweden and to some extent also in Finland they have good programmes and results from systematic and proactive support to enterprises, employers and employees who are facing severe restructuring and downsizing. Other countries could be inspired, and learn from their experiences.

Extensive pension reforms have been and are being implemented in all the Nordic countries. The main objective is to make the pension systems more sustainable in the long term, with good intergenerational balance of benefits and costs. Central elements of the pension reforms implemented are improved incentives and mechanisms to stimulate to longer working lives, curbing early retirement schemes, and by giving more flexibility in the transition between work and retirement.

One upcoming pension policy challenge may stem from a bit too one-sided focus on work incentives to the expense of social redistribution purposes of the public pension systems(?) In some Nordic, and other European, countries they are now considering or implementing improved pension solutions for people with low income, unregulated working conditions and insecure labour market participation.

Encouraging employers to retain and hire older workers. Most initiatives and reforms to increase the labour market participation of older workers have so far been implemented on the supply side of the labour market. In particular by strengthened work incentives in pension reforms and active labour market measures. There have been fewer and weaker initiatives on the demand side of the labour market. Namely by encouraging employers to retain and hire older workers. Employers are usually more willing to retain than to hire older workers. The retention rates of older workers are quite high and the hiring rates quite low in the Nordic countries.

Age discrimination in the labour market is forbidden by law in the Nordic countries, but both age discrimination and age stereotypical attitudes and behaviour exist (SOU 2020:69). This is most common when it comes to recruitment and hiring processes. Employers and line managers often appreciate their older employees, because of their work experience, loyalty and responsibility. But they are more hesitant to hire older workers; the main reason may be actual or perceived obsolete competence and reduced productivity. In three of the Nordic countries: Denmark, Norway and Sweden, the governments have set up national and tripartite anchored institutions to provide knowledge-based information, advice and awareness-raising about such kinds of issues and questions.

Promoting employability throughout the whole working life. Results from the OECD Survey of Adult Skills (PIAAC) suggest that older workers across the OECD are not, on average, well equipped to deal with changes in skill requirements brought about by technological developments and globalisation. This is the situation in the Nordic countries as well. Older workers with less recent vintages of skills are particularly exposed to the risk of skills 
obsolescence. In addition, older workers participate far less than younger workers in jobrelated training, (OECD, 2016).

Such challenges are quite broadly acknowledged on a national level in the Nordic countries, and highlighted in several governmental policy documents and initiatives. Some concrete policy and practice initiatives have also been implemented. But more could be done, especially in practice, on regional-, industry- and enterprise level, and last but not least on the individual level.

\section{References}

Fremtidens seniorarbejdsliv - anbefalinger fra Seniortænketanken. Beskæftigelsesministeriet 2019

Halvorsen, Bjørn (2020) Senior Citizens:_Work and Pensions in the Nordics. Report 17. Swedish Governmental Delegation for Senior Workforce.

Halvorsen, Bjørn (2019) Hva kan vi lære av våre naboland? Om å forebygge og begrense frafall i arbeidslivet som følge av omstillinger og nedbemanninger? SSP memo report no 2/2019

Meld. St.14 (2019-2020) Kompetansereformen - Lære hele livet

Norsk seniorpolitisk barometer 2019 og 2020. Rapport utarbeidet av Ipsos for Senter for seniorpolitikk

NOU 2019: 17 Arbeid og inntektssikring. Tiltak for økt sysselsetting

OECD (2016) Skills Matter: Further results from the Survey of Adult Skills, OECD Skills Studies

OECD (2019) Working Better with Age, and OECD Older Workers Scoreboard

SOU 2020:69 Eldre har aldrig varit yngre - allt fler kan och vill arbeta lengre

\section{About the author}

Bjørn Einar Halvorsen is retired Director General and Special Adviser from the Ministry of Labour and Social Affairs and from the Centre for Senior Policy in Norway 